\title{
DINAMIKA KOMUNIKASI ANTAR PASANGAN
}

\author{
Fitra Yeni ${ }^{\mathrm{a}}$ \\ ${ }^{a}$ Fakultas Keperawatan Universitas Andalas \\ E-mail: fitra.yeni@rocketmail.com
}

\begin{abstract}
Communication is a someone ability to express their feeling and an ability to understanding others. Communication and intimacy are related, because communication is a key of intimacy. Lack of skills to communicate each other in spouse will take a great deal to cause a maarriege conflict. Marriage conflict can effect a divorce. This study use phenomonology study. The participants in this study are man and his spouse who have children. The result of this study showed that the participants have their own style in communication with their spouse. A men have no problem in communication with thwir spouse, but in the other side, women showed the disappointed expression in communication with their spouse because the differentiation in background. The participants have their own effort in order to have an understanding meaning each other, such as build the interaction, have a same perception, give the rewards and punishment, talk fluently, anger, and courious. The participants tell that communication can affect the development of family postively and negatively.
\end{abstract}

Key words:

Abstrak: Komunikasi merupakan kemampuan seseorang untuk mengekspresikan perasaan mereka dan kemampuan untuk memahami orang lain. Komunikasi dan keintiman adalah dua hal yang sangat berhubungan karena komunikasi adalah kunci keintiman. Kurangnya keterampilan untuk melakukan komunikasi dengan pasangan akan memiliki potensi besar untuk menimbulkan konflik perkawinan. Konflik perkawinan dapat menimbulkan ketidakbahagiaan, kekerasan dalam rumah, menurunkan produktivitas kerja dan lebih lanjut menimbulkan perceraian. Penelitian ini menggunakan metode fenomenologi. Partisipan (responden) dalam penelitian ini adalah pasangan suami-istri dan telah mempunyai anak. Hasil penelitian menunjukkan bahwa para responden mempunyai gaya tersendiri dalam berkomunikasi dengan pasangan. Suami tidak memiliki kendala dalam berkomunikasi dengan istri tetapi sebaliknya istri kurang puas berkomunikasi dengan suami karena latar belakang yang berbeda. Para responden telah melakukan usaha-usaha agar pasangan mengerti apa yang mereka inginkan, seperti membangun interaksi, menyamakan persepsi, memberikan reward dan punishment, bicara baik-baik, marah-marah dan "cuek" terhadap apa yang terjadi. Para responden menyebutkan bahwa komunikasi dapat mempengaruhi perkembangan keluarga baik positif maupun negatif

Kata kunci: komunikasi antar pasangan, perkembangan keluarga 
PENDAHULUAN

Komunikasi adalah faktor penting dalam hubungan manusia. Saat sebuah hubungan dibangun maka dengan komunikasilah akan muncul sebuah keintiman. Semua hubungan apapun itu tergantung kepada bagaimana gaya berkomunikasi, cara berkomunikasi, dan keterampilan mengembangkan keduanya. Kemampuan dan kemauan pasangan untuk berkomunikasi dapat menciptakan hubungan yang sehat dan bahagia diantara pasangan.

Komunikasi dan keintiman adalah dua hal yang sangat berhubungan karena komunikasi adalah kunci keintiman. Pasangan, terutama yang dikategorikan sebagai pasangan yang tidak bahagia selalu mengeluh bahwa,'Kami tidak melakukan komunikasi". Padahal hal itu sangatlah tidak mungkin. Tetapi faktanya komunikasi yang dilakukan dengan berbagai cara, seperti saling berbicara, kontak fisik, dan saling memberikan senyum, sering absen dalam hubungan pernikahan. Dimasa awal hubungan, pasangan selalu melihat kepada hal-hal positif yang dimiliki satu sama lain dan mengabaikan hal- hal negatif dari pasangannya. Tetapi lama kelamaan setelah tahun demi tahun dilewati, mulailah melihat kepada hal-hal negatif dan tidak bisa lagi melihat adanya hal-hal positif. John Gottman dkk mengadakan penelitian yang melibatkan 2000 pasangan yang telah menikah dan ditemukan bahwa pasangan yang berbahagia ternyata mengekspresikan komunikasi negatif dan positif dengan seimbang. Hal ini berarti untuk menjadikan sebuah hubungan menjadi bahagia tidak perlu menghindari komunikasi yang negatif (Olson, Olson, 2000).

Sementara itu, pernikahan kuat sekali manfaatnya bagi individu dan masyarakat Pernikahan yang kuat akan menghasilkan emosi yang sehat, hubungan seksual yang sehat dan kepuasan secara ekonomi serta menghindarkan diri dari penyakit masyarakat. Hal ini akan berdampak langsung pada kesejahteraan individu itu sendiri, anak-anak serta komunitas disekitarnya (Liddle, Santisteban, Levant, Bray, 2002). Tentunya ini membutuhkan komunikasi yang efektif antar pasangan.

Kurangnya keterampilan untuk melakukan komunikasi dengan pasangan akan memiliki potensi besar untuk menimbulkan konflik perkawinan. Konflik perkawinan dapat menimbulkan ketidakbahagiaan, kekerasan dalam rumah, menurunkan produktivitas kerja dan lebih lanjut menimbulkan perceraian. Sementara perceraian dapat menimbulkan dampak negatif pada tumbuh kembang anggota keluarga terutama anak. Anak yang tinggal dengan kedua orang tuanya lebih memperlihatkan prestasi yang bagus disekolah, populer dikalangan temantemannya. Sedangkan anak dari orang tua yang bercerai lebih memperlihatkan prestasi yang rendah dan masalah emosional. Jika anak korban perceraian telah dewasa, mereka memperlihatkan kecenderungan tinggal bersama dengan pasangannya (cohibition/ kumpul kebo) dan juga memiliki kecenderungan bercerai setelah menikah (Olson, www.lifeinnovation.com).

Pentingnya komunikasi terhadap kebahagiaan dalam keluarga membuat saya tertarik untuk melihat bagaimana dinamika komunikasi antar pasangan dan dampaknya terhadap perkembangan keluarga. Penelitian ini bertujuan untuk mengetahui bagaimana pasangan berkomunikasi dalam keluarga dan apa dampak dari komunikasi yang mereka gunakan terhadap perkembangan keluarga.

\section{METODE}

Penelitian ini menggunakan metode fenomenologi. Partisipan (responden) dalam penelitian ini adalah pasangan suami-istri dan telah mempunyai anak. Pengumpulan data menggunakan interview yang dilakukan melalui tape recorder kemudian menganalisis data yang diperoleh. 


\section{HASIL DAN PEMBAHASAN}

Pada dasarnya ada perbedaan antara suami dan istri dalam memandang komunikasi. Suami lebih menekankan pada tujuan berkomunikasi sementara istri lebih menekankan pada proses berkomunikasi. Perbedaan cara pandang ini merupakan pemicu konflik dalam berkomunikasi karena bisa jadi sesuatu hal menjadi tidak penting bagi suami sehingga tidak perlu dikomunikasikan, sementara menurut istri hal tersebut merupakan sesuatu yang penting dan perlu dikomunikasikan. Secara singkat hasil penelitian dapat dilihat pada gambar berikut:

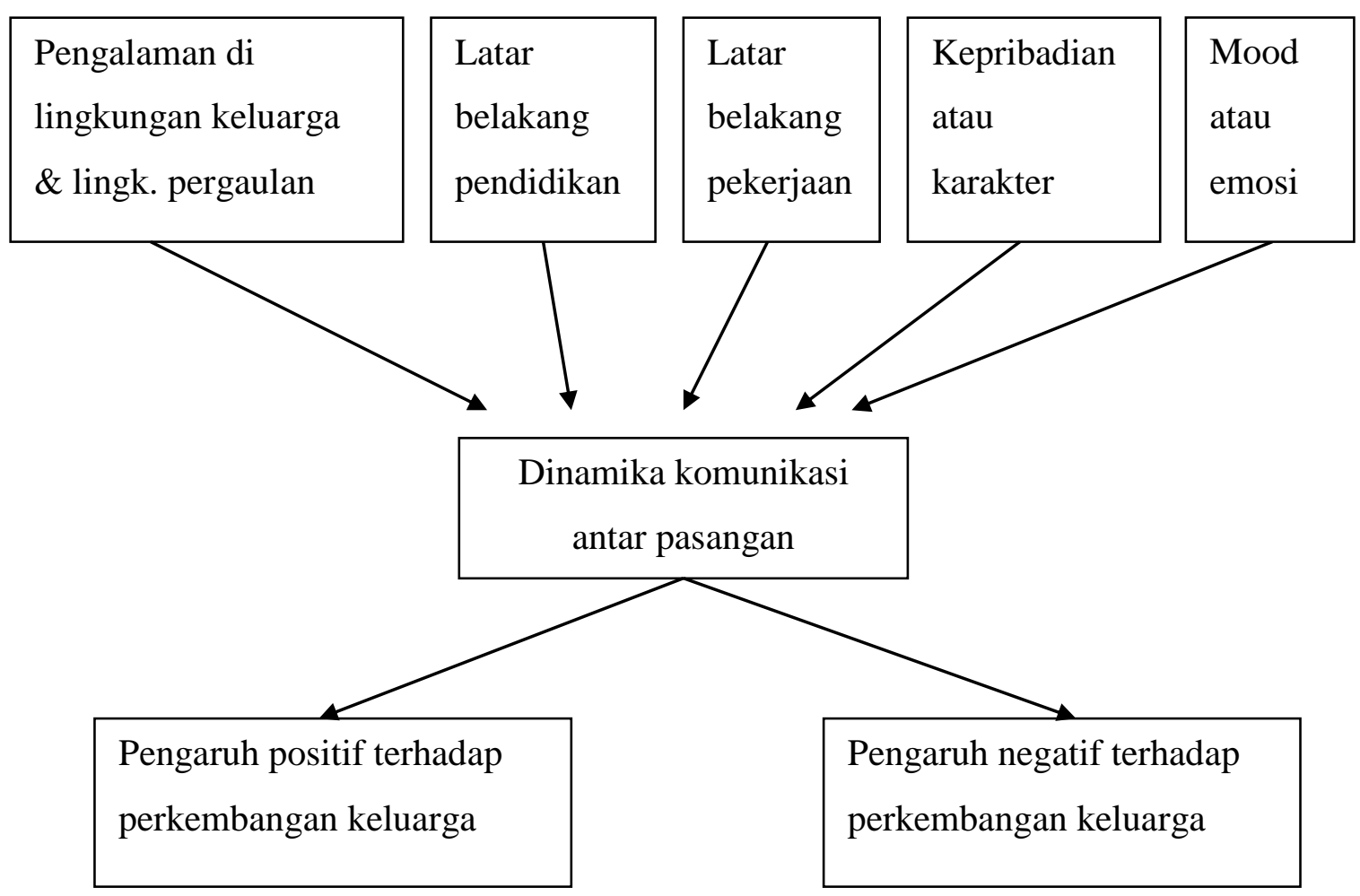

Gambar: Hasil penelitian 


\section{Komunikasi adalah saling memberi dan menerima informasi}

Menurut para responden, komunikasi antar pasangan merupakan interaksi suami-istri yang didalamnya ada saling memberi dan menerima informasi, dan saling memberi dan menerima masukan. Informasi yang diberikan sifatnya terbuka, artinya tidak ada yang perlu dirahasiakan dari masing-masing pasangan. Informasi juga diartikan oleh salah seorang responden sebagai cara untuk menyelesaikan masalah. Komunikasi tidak berhasil apabila pasangan tidak memahami apa yang kita maksud, untuk itu kita perlu mengevaluasi kembali apakah pesan kita diterima oleh pasangan dengan memperhatikan respon yang diberikan oleh pasangan.

Sesuai dengan pendapat para responden, Olson (2000) menyatakan bahwa komunikasi merupakan kemampuan untuk mengekspresikan perasaan dan memahami sesuatu. Bimo (2000) juga menyebutkan bahwa komunikasi antara suami istri harus saling terbuka dan berlangsung dua arah. Dengan komunikasi yang terbuka maka akan terbina saling pengertian sehingga terhindar dari kesalahpahaman. Komunikasi terbuka juga dapat membantu pasangan untuk mengidentifikasi kelemahan dan kekuatan pasangan sehingga dapat menetapkan tujuan sesuai dengan kemampuan.

\section{Perbedaan pengalaman hidup: kendala dalam berkomunikasi}

Para responden mengatakan bahwa

pengalaman hidup seseorang dan kepribadian yang terbentuk dari pengalaman hidup itu sendiri, sering menjadi kendala dalam berkomunikasi dengan pasangan sehingga komunikasi menjadi tidak efektif. Pengalaman hidup ini meliputi lingkungan di keluarga dan lingkungan pergaulan, latar belakang pendidikan, dan latar belakang pekerjaan. Pengalaman hidup ini akan membentuk kepribadian seseorang dan kepribadian akan mewarnai sikap seseorang.

Pengalaman di lingkungan keluarga dan lingkungan pergaulan yang positif akan membentuk kepribadian yang positif, sehingga individu seperti ini akan "nyambung" kalau diajak berkomunikasi. Namun tidak semua pengalaman positif membuat komunikasi menjadi efektif karena pengalaman positif sangat ditentukan oleh nilai-nilai setempat. Contohnya, salah seorang responden mengatakan bahwa karena suaminya mempunyai pengalaman tentang ibunya yang selalu membuatkan minuman untuk ayahnya, maka suaminya juga menuntut istrinya untuk melakukan hal yang sama. Ketika istri menolak dengan memberikan alasan-alasan tertentu, ternyata suami tidak dapat menerima dan menuduh istri tidak menjalankan perannya. Sementara istri tidak mempunyai pengalaman tentang ibu yang membuatkan minuman untuk suami dan tidak dapat digunakan senagai alat ukur "peran istri". Di sisi yang lain, apabila pengalaman tersebut negatif maka kepribadian yang terbentuk juga akan negatif. Contohnya, menurut salah seorang responden, orang yang punya trauma masa lalu sehingga dia selalu curiga dengan orang lain. Orang seperti ini akan sulit diajak berkomunikasi karena cenderung "negative thinking".

Pengalaman ini sangat berpengaruh terhadap pembentukan kepribadian seseorang melalui pola asuh dalam keluarga. Menurut para responden, budaya tidak memberikan banyak pengaruh karena pengalaman dari para responden bahwa orang dari daerah yang sama tidak selalu menunjukkan perilaku yang sama. Namun pemahaman tentang nilai-nilai yang umum, seperti laki-laki adalah pimpinan dalam keluarga, memberikan dampak yang sangat besar. Istri merasa suami selalu minta diakui bahwa suami adalah pimpinan dalam rumah tangga sehingga suami merasa posisinya lebih tinggi dari suami. Nilai-nilai ini semakin kuat apabila diterapkan dalam keluarga asal mereka. 
Istri merasa suami cenderung otoriter dalam keluarga. Permasalahannya adalah kenyataannya pada pasangan muda saat ini, mereka lebih menuntut kesetaraan peran dalam perkawinan.

Menurut peneliti, telah terjadi pergeseran nilai-nilai budaya yang mungkin berbenturan dengan perubahan sosial sehingga memicu terjadinya konflik. Masing-masing pasangan harus dapat beradaptasi dengan perubahan tersebut agar konflik tidak terjadi (Liddle, 2002). Memang tidak mudah merubahnya karena nilai-nilai ini mungkin telah menjadi bagian dari keribadian dan merubah kepribadian adalah hal yang sulit. Namun kekakuan yang kita ciptakan dalam keluarga justru akan menimbulkan disfungsi keluarga, salah satunya adalah komunikasi yang patologis.

Perbedaan latar belakang pendidikan dan pekerjaan akan menimbulkan sudut pandang yang berbeda ketika menilai suatu hal. Pengalaman responden yang lain menyebutkan bahwa kesulitan dalam menyamakan persepsi sehingga visi dan misi dalam keluarga juga berbeda. Pendidikan dan pekerjaan juga memberikan pengaruh terhadap harga diri. Suami dengan pendidikan dan pekerjaan yang lebih rendah posisinya dari istri ada yang merasa "takut" dengan istrinya sehingga yang menjadi decision maker lebih banyak istri. Yang menarik, ternyata pekerjaan kadang-kadang menyita sebagian besar waktu sehingga kendala dalam berkomunikasi adalah "tidak ada waktu yang tepat untuk "ngobrol" dengan alasan kelelahan.

Menurut Katz (Bimo, 2000 dikutip dari Secord \& Backman, 1964), sikap dalam hubungannya dengan komunikasi terkait dengan keterlibatan fungsi sikap itu sendiri. Pertama adalah sikap sebagai ekspresi nilai, bahwa sikap seseorang menunjukkan bagaimana nilai-nilai yang ada pada orang tersebut. Kita dapat memahami sikap suami dan istri tentang membuatkan air minum untuk suami karena masing-masing mempunyai nilai- nilai sendiri yang mereka dapatkan dari pengalaman di lingkungan keluarga. Kedua adalah sikap sebagai pertahan ego, dimana seseorang mengambil sikap tertentu karena hanya untuk mempertahankan egonya atau akunya. Kita juga dapat memahami tentang sikap suami yang cenderung otoriter karena ingin mempertahankan egonya. Ketiga adalah sikap sebagai pengetahuan, bahwa sikap seseorang terhadap sesuatu objek mencerminkan keadaan pengetahuan dari orang yang bersangkutan. Perbedaan latar belakang pendidikan dan pekerjaan dapt menyebabkan perbedaan pengetahuan dan pemahaman sehingga terdapat perbedaan dalam memandang suatu persoalan. Dengan demikian, kita dapat memahami bahwa perbedaan dalam memandang sesuatu terjadi karena refleksi dari pengetahuan ada pada masing-masing pasangan. Keempat adalah sikap sebagai instrumen atau alat mencapai tujuan, bahwa sikap seseorang terhadap suatu objek ditentukan oleh sampai sejauh mana objek tersebut dapat digunakan untuk mencapai tujuan. Kita dapat memahami bahwa perubahan mungkin akan menjadi sesuatu yang sulit apabila kita tidak memahami kebaikan yang ditimbulkan dari perubahan tersebut.

Ditambahkan oleh Olson (2000), kemampuan berkomunikasi ini menjadi sulit karena kesalahan yang kita lakukan dalam berkomunikasi. Pertama adalah membuat asumsi. Terkadang kita merasa tahu betul perasaan pasangan kita tanpa menanyakannya secara langsung, padahal hal ini bisa menimbulkan masalah komunikasi. Yang salah disini adalah individu melihat pengalaman-pengalaman sebelumnya dan berasumsi bahwa pasangannya tidak berubah. Padahal perasaan, ide sering sekali berubah. Berasumsi mengenai perasaan dan pemikiran pasangan akan membuat penurunan komunikasi dan rendahnya keinginan untuk saling berbagi serta keintiman. Kedua adalah merubah komunikasi positif menjadi komunikasi 
negatif. Dimasa awal hubungan, pasangan selalu melihat kepada hal-hal positif yang dimiliki satu sama lain dan mengabaikan hal- hal negatif dari pasngannya. Tetapi lama kelamaan setelah tahun demi tahun dilewati, mulailah melihat kepada hal-hal negatif dan tidak bisa lagi melihat adanya hal-hal positif. John Gottman dkk mengadakan penelitian yang melibatkan 2000 pasangan yang telah menikah dan ditemukan bahwa pasangan yang berbahagia ternyata mengekspresikan komunikasi negatif dan positif dengan seimbang. Hal ini berarti untuk menjadikan sebuah hubungan menjadi bahagia tidak perlu menghindari komunikasi yang negatif. Ketiga adalah gagal dalam mendengarkan. Mengapa kemampuan berkomunikasi harus dimiliki? Karena sering kita hanya mendengar orang berbicara (hear) tapi tidak mendengarkannya (listen). Untuk dapat berkomunikasi secara efektif dengan orang lain kita harus belajar bagaimana cara mendengarkan. Karena hal ini dapat mengurangi munculnya kesalahpahaman dan konflik.

Pengalaman responden yang lain menyebutkan bahwa Mood dan emosi ternyata juga dapat menjadi kendala dalam komunikasi. Komunikasi menjadi kegiatan yang sulit apabila dilakukan saat "tidak mood". Tentunya ini juga dipengaruhi oleh kepribadian seseorang karena ada orang yang tidak ada kesulitan diajak berkomunikasi walupun suasana hatinya buruk.

\section{Supaya aman, ya udah, nikmati saja.}

Dengan latar belakang pendapat yang berbeda, tampaknya responden juga menggunakan gaya komunikasi yang berbeda. Para suami tidak bermasalah dengan komunikasi yang mereka terapkan dirumah, namun para istri merasa kesulitan berkomunikasi dengan suami mereka karena perbedaan tersebut. Para responden telah melakukan usaha-usaha agar pasangan mengerti apa yang mereka inginkan, seperti membangun interaksi, menyamakan persepsi, memberikan reward dan punishment, bicara baik-baik, marah-marah dan "cuek" terhadap apa yang terjadi. Para istri lebih memilih mengalah apabila apa yang mereka komunikasikan tidak mendapatkan respon seperti yang diharapkan.

Dari sudut pandang peneliti, kesulitan pasangan dalam membangun komunikasi karena kurangnya pengetahuan bagaimana cara membangun komunikasi yang efektif dan bukan nilainilai yang umum diterapkan sehingga kemungkinan pasangan merasa "kaku" untuk melakukannya. Menurut Olson (2000), ada beberapa cara untuk meningkatkan komunikasi dengan pasangan. Pertama adalah sediakan waktu untuk berdialog 5 menit setiap hari dan 15 menit di akhir pekan untuk membahas tentang perasaan masing- masing. Pasangan yang selalu menunda untuk membicarakan sesuatu maka secara berkala mereka akan menjadi apatis satu sama lain. Kedua adalah membuka diri. Keterbukaan diri mempunyai pengaruh timbal balik, yaitu saat kita percaya kepada orang lain maka secara langsung mereka juga akan meningkatkan kepercayaan kepada kita. Menceritakan hal-hal pribadi kepada orang lain tidak hanya akan membuat orang lain tahu tentang diri kita tetapi kita juga bisa lebih memahami diri kita sendiri. Dengan menceritakan tentang diri ataupun pengalaman hidup yang pribadi kepada pasangan maka kita telah membawa hubungan menjadi lebih dalam atau lebih dekat. Ketiga adalah asertif. Asertif adalah kemampuan mengekspresikan perasaan dan menyakan apa yang diinginkan. Kempat adalah mendengar aktif. Pendengar aktif adalah kemampuan untuk mendengarkan sesuatu dengan akurat dan mengulanginya kembali kepada yang mengucapkan. Perbedaan pendengar asertif dan pendengar aktif: Asertif, "Aku sangat menikmati waktu yang aku habiskan bersamamu, tetapi aku juga butuh waktu bersama teman-temanku. $\mathrm{Aku}$ ingin kita membicarakannya dilain 
waktu"; Aktif, "Aku dengar kamu berkata bahwa kamu menikmati waktu yang kita habiskan bersama, tetapi kamu butuh waktu untuk teman-temanmu. Kamu ingin kita mengatur waktu untuk membicarakannya?". Kelima adalah pujian setiap hari. Berikanlah pujian kepada apa yang telah pasanganmu lakukan. Berikanlah semangat kepadanya. Dengan memberikan paling tidak sekali pujian dalam sehari kepada pasangan dapat membantu kita fokus pada kekuatan diri sebagai individu.

Para responden menyadari bahwa komunikasi yang tidak efektif akan membuat ketidakbahagian dalam keluarga dan akan mempengaruhi tumbuh kembang keluarga umunya dan anak khususnya. Gaya komunikasi yang diterapkan oleh responden sat ini dianggap oleh responden merupakan gaya komunikasi terbaik yang mereka miliki. Namun mereka menyebutkan bahwa gaya komunikasi yang mereka gunakan lebih kearah meminimalkan konflik, belum kearah menciptakan kebahagiaan.

\section{KESIMPULAN DAN SARAN}

Dari empat orang responden diperoleh hasil bahwa komunikasi merupakan kemampuan seseorang untuk mengekspresikan perasaan mereka dan kemampuan untuk memahami orang lain. Kendala yang ditemui ketika pasangan berkomunikasi adalah pengalaman di keluarga dan lingkungan pergaulan, latar belakang pendidikan, latar belakang pekerjaan, kepribadian dan mood/emosi. Dengan adanya perbedaan tersebut, para responden mempunyai gaya tersendiri dalam berkomunikasi dengan pasangan. suami tidak memiliki kendala dalam berkomunikasi dengan istri tetapi sebaliknya istri kurang puas berkomunikasi dengan suami. Para responden menyebutkan bahwa komunikasi dapat mempengaruhi perkembangan keluarga baik positif maupun negatif.
Saran yang dapat diberikan dari hasil penelitian ini adalah perlu adanya kajian lebih lanjut tentang kemampuan pasangan dalam berkomunikasi dan perlu adanya kajian lebih lanjut tentang pengaruh komunikasi terhadap perkembangan keluarga. 